\title{
Microtextural and mineral chemical analyses of andesite-dacite from Barren and Narcondam islands: Evidences for magma mixing and petrological implications
}

\author{
DWiJesh RaY*, S RaJan, Rasik RaVindra and Ashim Jana \\ National Centre for Antarctic and Ocean Research, Goa 403 804, India. \\ *e-mail: dwijesh@rediffmail.com
}

\begin{abstract}
Andesite and dacite from Barren and Narcondam volcanic islands of Andaman subduction zone are composed of plagioclase, orthopyroxene, clinopyroxene, olivine, titanomagnetite, magnesiohornblende and rare quartz grains. In this study, we use the results of mineral chemical analyses of the calc-alkaline rock suite of rocks as proxies for magma mixing and mingling processes. Plagioclase, the most dominant mineral, shows zoning which includes oscillatory, patchy, multiple and repetitive zonation and 'fritted' or 'sieve' textures. Zoning patterns in plagioclase phenocrysts and abrupt fluctuations in An content record different melt conditions in a dynamic magma chamber. 'Fritted' zones $\left(A n_{55}\right)$ are frequently overgrown by thin calcic $\left(A n_{72}\right)$ plagioclase rims over welldeveloped dissolution surfaces. These features have probably resulted from mixing of a more silicic magma with the host andesite. Olivine and orthopyroxene with reaction and overgrowth rims (corona) suggest magma mixing processes. We conclude that hybrid magma formed from the mixing of mafic and felsic magma by two-stage processes - initial intrusion of hotter mafic melt (andesitic) followed by cooler acidic melt at later stage.
\end{abstract}

\section{Introduction}

Major, trace and isotopic composition of phenocrysts of intermediate rocks of andesite-rhyolitedacite association have been used as proxy indicators of magma mixing and contamination, and can be considered as tools for 'petrological fingerprinting' (e.g., Eichelberger 1978; Tepley et al 2000; Davidson et al 2001; Izbekov et al 2002). Plagioclase from the volcanic rocks also provides key information on various aspects of magma chamber dynamics on account of its relative abundance, wide range of crystallization temperature and the tendency to develop textural and compositional zoning during its growth (Coombs et al 2002; Izbekov et al 2002).
In this paper, we present the results of detailed petrographic and microtextural investigations carried out on a suite of andesitic and dacitic rocks from Barren and Narcondam volcanic islands of the Andaman-Nicobar subduction zone. The studies bring out the intricacy of the magmatic history of the area as reflected in the complex petrography of the erupted andesite and dacite. However, the role of magma mixing is poorly constrained in the volcanic rocks of both the islands.

\section{Geological setting}

The Andaman-Nicobar region marks the eastern margin of the Indian plate where the Indian plate

Keywords. Andesite; dacite; Barren island; Narcondam island; magma mixing. 


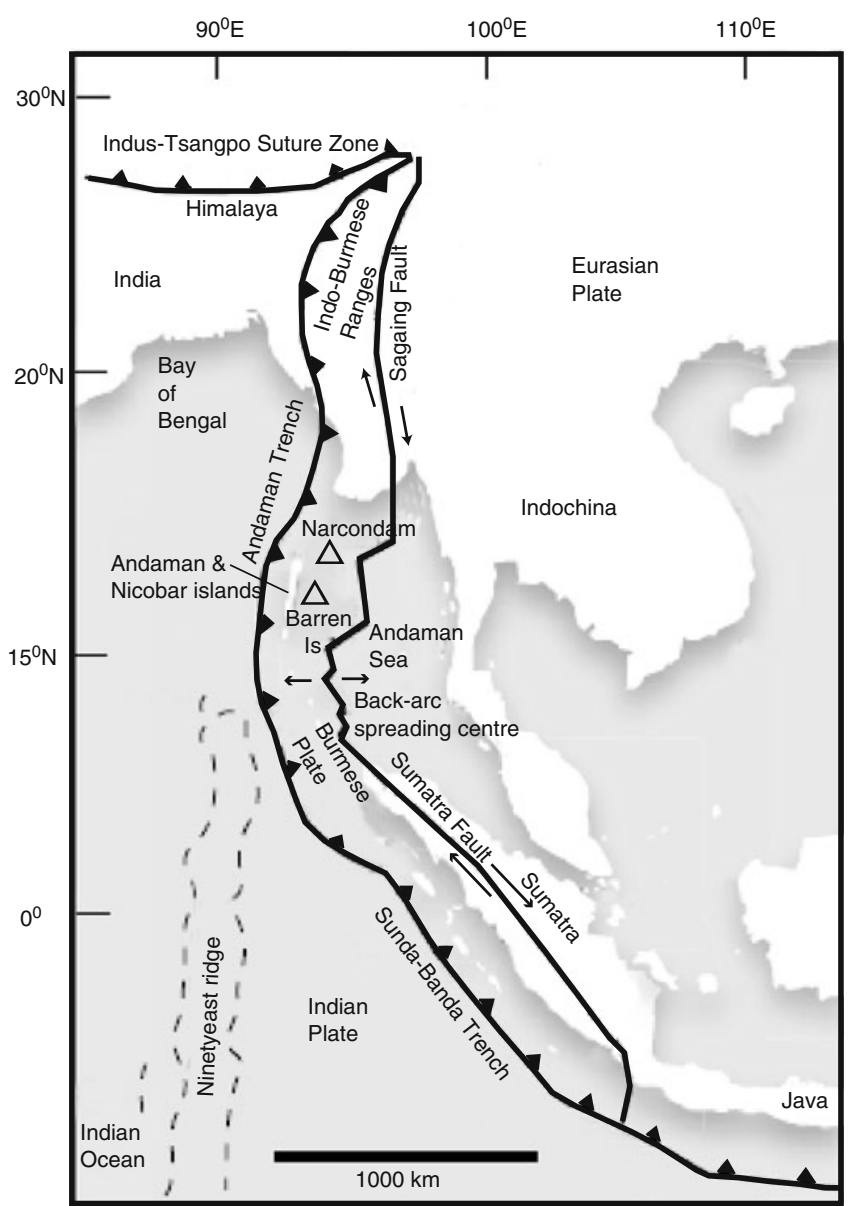

Figure 1. Map showing major geological and tectonic features of the Indian Ocean and the southeastern Asia, along with locations of Barren and Narcondam volcanic islands (triangles in the figure). Based on Sheth et al (2009).

converges obliquely with the Sunda plate. This zone of convergence has resulted in the formation of a major island arc-trench system (the BurmeseSunda arc system) extending for over $1000 \mathrm{~km}$ from Myanmar in the north to Sumatra in the south. The Andaman island arc comprising the Andaman-Nicobar islands and the Andaman back arc basin forms a part of this major arc-trench system.

The Andaman island arc (figure 1) is seismically very active. Its Benioff-Wadati plane extends down to a depth of $200 \mathrm{~km}$ (Radhakrishna et al 2008). Barren and Narcondam volcanic islands (triangles shown in figure 1) are two inner arc volcanoes of the Andaman-Nicobar subduction zone. Barren island is an active volcano which has experienced four phases of eruptions since 1803. In contrast, the Narcondam island is inactive.

Some of the earliest work on the volcanic islands of Anadaman-Nicobar have been carried out by the Geological Survey of India (GSI) during

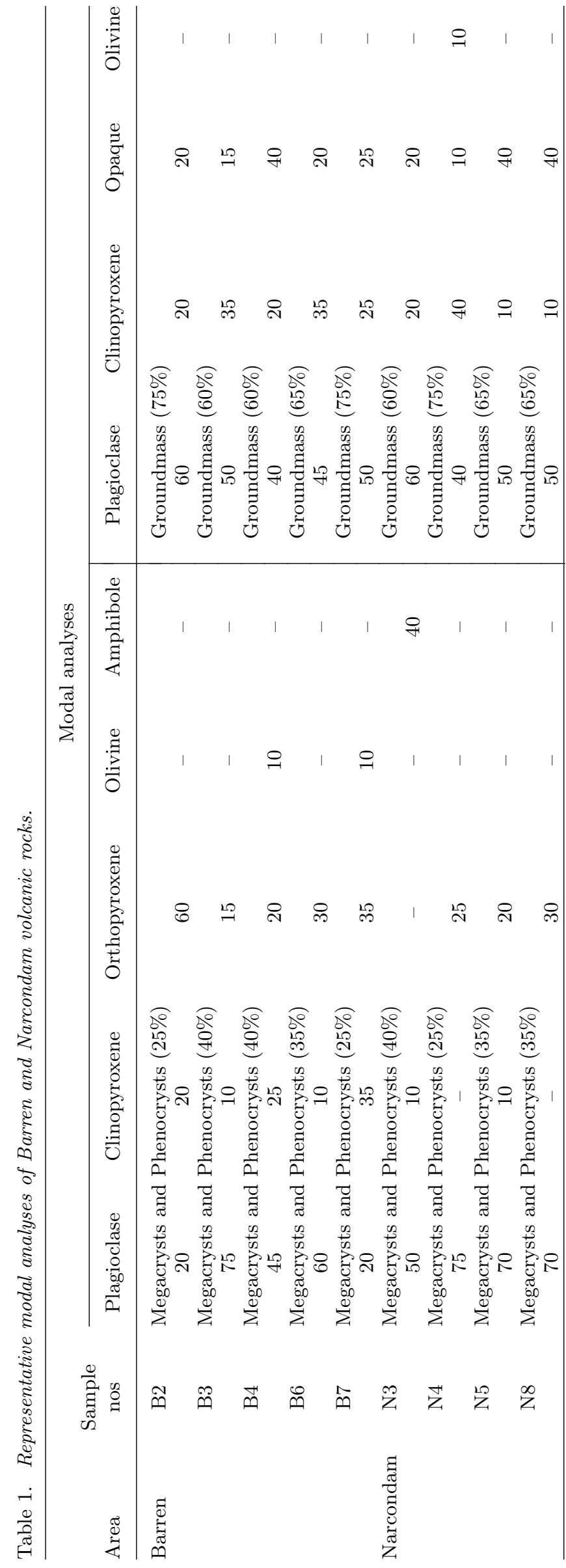


1884-1885. Recent petrological studies indicate that basaltic andesites are common on Barren islands while rhyodacites and dacites are found on Narcondam islands (Luhr and Halder 2006; Pal et al 2007; Chandrasekhar am et al 2009). Basaltic andesite from Barren island mainly represents the post-caldera rocks of the 1787-1832, 1991 and 1995-2000 events (Chandrasekharam et al 2009). Porphyritic basalt and basaltic andesite host phenocryst in varying proportions (up to $40 \%$ by volume, table 1). Rocks from Narcondam island are principally represented by dacite, amphibole-andesite and andesite. Megacryst and phenocryst proportions vary up to $40 \%$ in dacite while amphibole-andesite plagioclase and amphibole occupy almost in equal proportions $(\sim 40 \%$, table 1$)$. Clinopyroxene $(\sim 10 \%)$ is the other major phenocrystal constituent mineral (table 1). The reason behind these contrasting suites of rock associations among these two adjacent islands is, however, yet to be resolved.

\section{Data collection and analytical methods}

During 2008-2009, limited field traverses were carried out on the Barren and Narcondam islands as a prelude to a major planned multi-institutional endeavour of geological and structural characterizations of the Andaman subduction zone. Fresh samples of andesite, dacite and basaltic andesite were collected from recent flows during field traverses. Detailed textural and mineralogical studies of selected samples were carried out at the National Centre for Antarctic \& Ocean Research (NCAOR) and National Institute of Oceanography (NIO), Goa. Mineral chemical analyses were performed in CAMECA SX 100 using five wavelength dispersive spectrometers at the Central Petrological Laboratory of the Geological Survey of India (GSI). The analytical conditions were a $15-\mathrm{kV}$ accelerating voltage, 20-nA beam current and 20-40 s counting time. All analyses were performed in a point mode. The obtained data were reduced following the PAP correction procedure after Pouchou and Pichoir (1988). Natural mineral standards were employed for calibration and also to check the precision and accuracy of the instrument.

\section{Petrography}

\subsection{Barren island}

\subsubsection{Andesite}

Andesite of Barren island consists mainly of megacrysts/phenocrysts of plagioclase, pyroxene (both ortho- and clinopyroxene and olivine. Modal analyses of representative sample sets are given in table 1. Plagioclase dominates the megacryst and phenocrystal assemblage (up to $75 \%$, table 1). The plagioclase grains are mostly subhedral and exhibit twining. Zoning is relatively less common as compared to twining. Patchy zoning is noticed locally within the plagioclase. A few grains also show reaction texture with the groundmass. Plagioclase also shows melt inclusions with occasional fresh core and altered rim. Plagioclase phenocrysts also show a 'dusty' or 'fritted' zone mantling of the grains encircled by a fresh rim (figures 2a, 3a). Orthopyroxenes are mostly intensely fractured, with greenish or brownish tint and are closely associated with olivine (figure 2b). Locally, the size of orthopyroxene exceeds that of associated plagioclase and olivine grains (figure 2b). A xenocrystic origin for these crystals has been suggested by Luhr and Halder (2006). The clinopyroxenes mostly occur as microphenocrysts or within the groundmass. Olivines are mostly colourless, anhedral and/or corroded crystals. Alterations are also noticed along the fractures. Resorbed olivine grains are present with fresh core preserved at the centre (figure 2c). Pyroxene often occurs as corona of olivines (figure $3 \mathrm{~b}$ ). Opaques are mostly composed of titanomagnetite and ilmenite, and volumetrically comprise up to $5 \%$ in Barren andesite (table 1). Locally population of opaque also varies, i.e., they are mostly concentrated within groundmass rather in phenocrysts. Magnetite occurs as fine disseminations evenly distributed throughout the groundmass.

\subsection{Narcondam island}

\subsubsection{Andesite, dacite and amphibole andesite}

Plagioclase is the dominant megacrystal or phenocrystal phase (table 1). Petrographically, the andesites of Narcondam island are similar to those of Barren island, although the number of plagioclase grains with 'fritted' rims are more common in the Narcondam andesite and/or dacite (figure $2 \mathrm{~d})$. The width of the 'fritted' rim also varies from $\mathrm{mm}$-thin to $\mathrm{cm}$-thick bands (figure $2 \mathrm{~d}$ ). Plagioclase occurs as fresh, unreacted grains or as resorbed, reacted grains (figure 2e). Fresh grains show both twining and oscillatory zoning (figure $2 \mathrm{f}$ ) while the resorbed grains show altered and 'fritted' rims with fresh core. Phenocrysts often show inclusions of pyroxene, glasses or opaques. In dacite, the plagioclase mostly occurs as thick 'fritted' bands and as resorbed minerals. The width of the 'fritted' portion is wider in dacite as compared to andesite. 

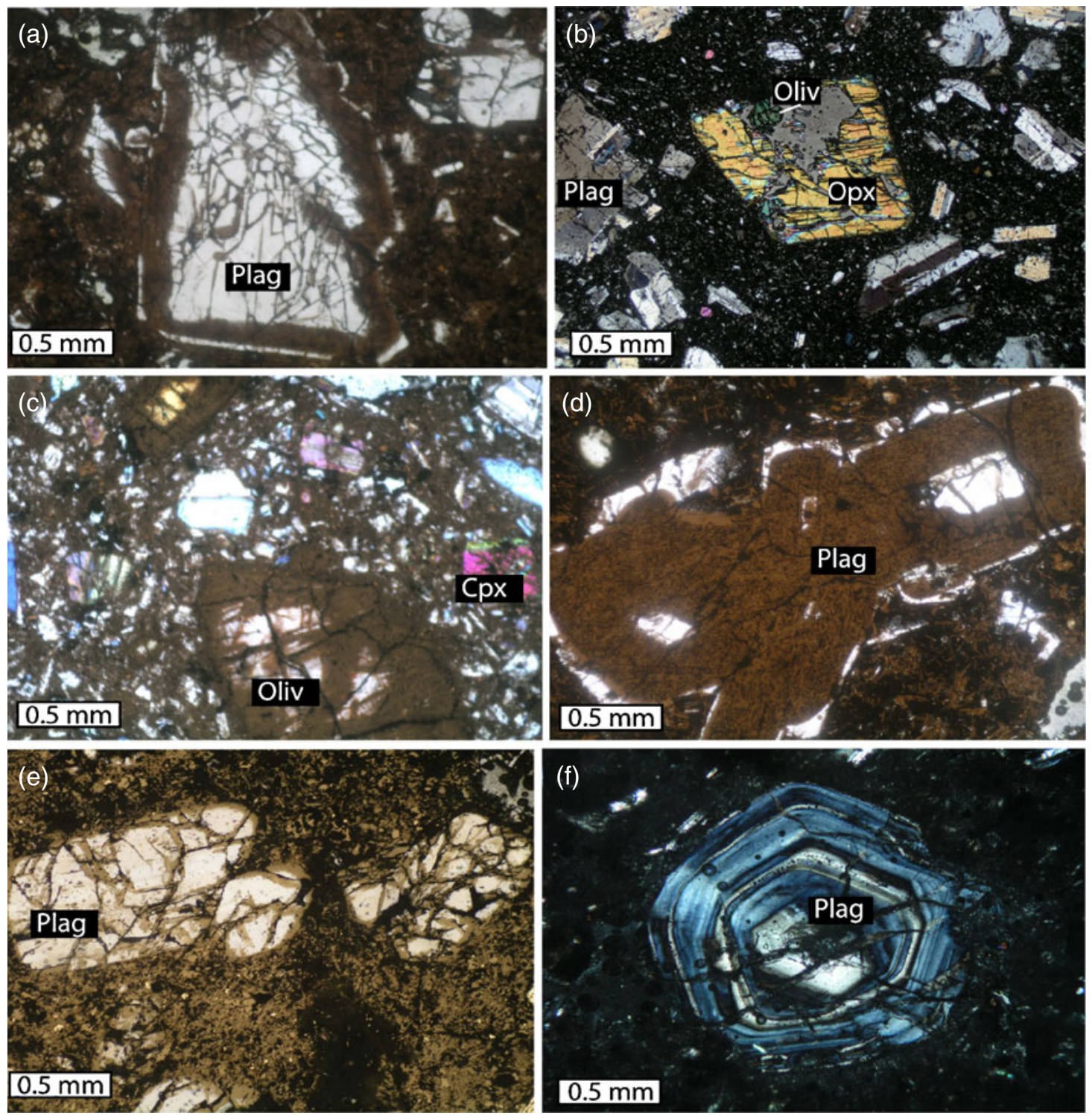

Figure 2. Photomicrographs of andesite and dacite rocks from Barren and Narcondam islands. (a) 'Fritted' plagioclase with calcic overgrowth at the rim. (b) Orthopyroxene megacryst and olivine in andesite. (c) Resorbed olivine with fresh core in andesite. (d) Wide 'fritted' plagioclase with fresh calcic core. (e) Resorbed plagioclase in dacite. (f) Oscillatory-zonned plagioclase. Plag: plagioclase, Oliv: olivine, Opx: orthopyroxene, Cpx: clinopyroxene.
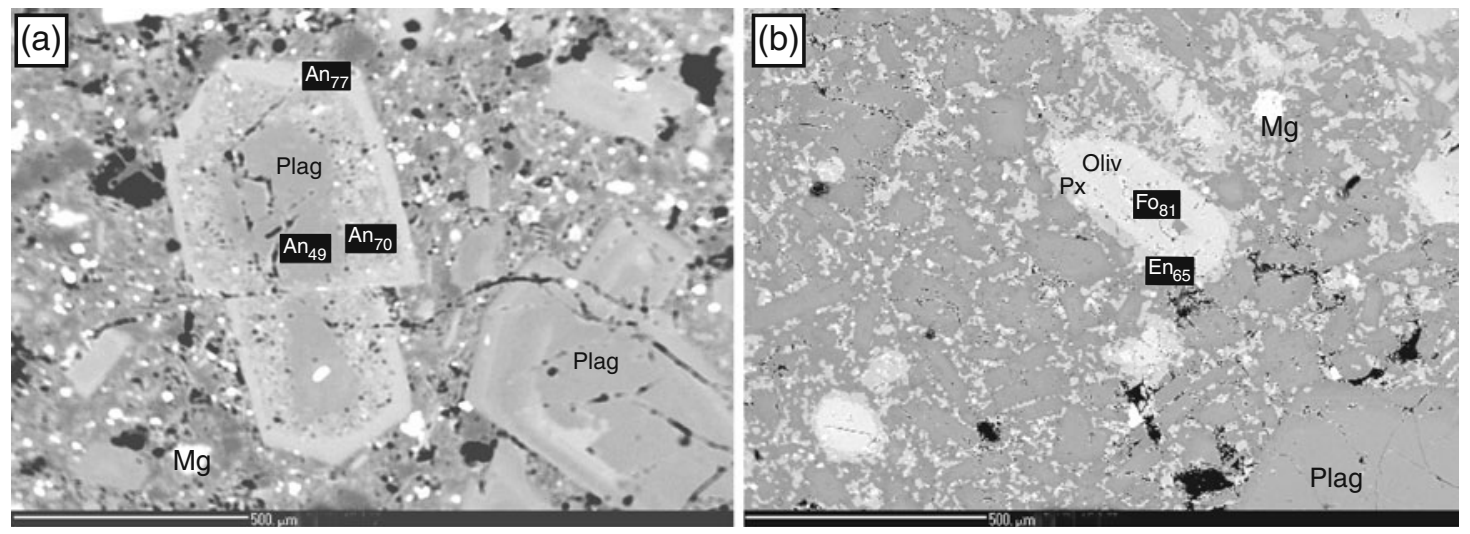

Figure 3. BSE (Backscattered electron) images of (a) 'fritted' plagioclase and (b) corona texture with olivine core and orthopyroxene rim. Corresponding chemical compositions (as end member) are also shown. Plag: plagioclase, Oliv: olivine, Px: pyroxene, Mg: magnetite. 
Table 2. Representative analyses of plagioclase phenocrysts and groundmass.

\begin{tabular}{|c|c|c|c|c|c|c|c|c|c|}
\hline \multirow{2}{*}{$\begin{array}{l}\text { Sample } \\
\text { nos }\end{array}$} & \multicolumn{4}{|c|}{ Barren } & \multicolumn{5}{|c|}{ Narcondam } \\
\hline & B-7 & B-3 & B-7 & B-7 & $\mathrm{N}-5$ & $\mathrm{~N}-8$ & $\mathrm{~N}-8$ & $\mathrm{~N}-8$ & $\mathrm{~N}-8$ \\
\hline Position & plag-gm & plag-gm & plag-core & plag-rim & plag-gm & plag-gm & plag-core & plag-int (fritted) & plag-rim \\
\hline $\mathrm{SiO}_{2}$ & 57.9 & 59.05 & 44.64 & 46.26 & 56.52 & 52.15 & 56.22 & 50.63 & 48.57 \\
\hline $\mathrm{TiO}_{2}$ & 0.1 & 0.12 & 0.01 & 0.03 & 0 & 0.02 & 0 & 0.08 & 0.02 \\
\hline $\mathrm{Al}_{2} \mathrm{O}_{3}$ & 24.98 & 24.53 & 34.39 & 32.97 & 27.25 & 30.07 & 27.33 & 30.95 & 31.6 \\
\hline $\mathrm{Cr}_{2} \mathrm{O}_{3}$ & n.d. & n.d. & n.d. & n.d. & n.d. & n.d. & n.d. & n.d. & n.d. \\
\hline $\mathrm{FeO}$ & 1.08 & 1 & 0.55 & 0.54 & 0.29 & 0.42 & 0.1 & 0.57 & 0.69 \\
\hline $\mathrm{MnO}$ & n.d. & 0.01 & n.d. & 0.04 & 0.07 & n.d. & n.d. & 0.02 & n.d. \\
\hline $\mathrm{MgO}$ & 0.05 & 0.01 & 0.07 & 0.08 & 0.02 & 0.03 & 0.02 & 0.04 & 0.05 \\
\hline $\mathrm{CaO}$ & 8.18 & 7.38 & 19.14 & 17.48 & 9.77 & 13.18 & 10.3 & 14.3 & 16.03 \\
\hline $\mathrm{Na}_{2} \mathrm{O}$ & 7 & 7.31 & 0.96 & 1.59 & 5.95 & 4.06 & 5.74 & 2.96 & 2.58 \\
\hline $\mathrm{K}_{2} \mathrm{O}$ & 0.56 & 0.47 & 0.01 & 0.01 & 0.27 & 0.26 & 0.35 & 0.67 & 0.15 \\
\hline $\mathrm{P}_{2} \mathrm{O}_{5}$ & 0.06 & 0.03 & 0.15 & 0.16 & 0.12 & 0.15 & 0.07 & 0.16 & 0.23 \\
\hline Total & 99.91 & 99.91 & 99.92 & 99.16 & 100.26 & 100.34 & 100.13 & 100.38 & 99.92 \\
\hline \multicolumn{10}{|c|}{ Cations based on 8 oxygens } \\
\hline $\mathrm{Si}$ & 2.617 & 2.657 & 2.075 & 2.155 & 2.541 & 2.369 & 2.531 & 2.311 & 2.24 \\
\hline $\mathrm{Ti}$ & 0.003 & 0.004 & 0 & 0.001 & 0 & 0.001 & 0 & 0.003 & 0.001 \\
\hline $\mathrm{Al}$ & 1.331 & 1.301 & 1.884 & 1.81 & 1.444 & 1.61 & 1.45 & 1.665 & 1.718 \\
\hline $\mathrm{Cr}$ & n.d. & n.d. & n.d. & n.d. & n.d. & n.d. & n.d. & n.d. & n.d. \\
\hline $\mathrm{Fe}$ & 0.041 & 0.038 & 0.021 & 0.021 & 0.011 & 0.016 & 0.004 & 0.022 & 0.027 \\
\hline $\mathrm{Mn}$ & n.d. & n.d. & n.d. & 0.002 & 0.003 & n.d. & n.d. & 0.001 & n.d. \\
\hline $\mathrm{Mg}$ & 0.003 & 0.001 & 0.005 & 0.006 & 0.001 & 0.002 & 0.001 & 0.003 & 0.003 \\
\hline $\mathrm{Ca}$ & 0.396 & 0.356 & 0.953 & 0.872 & 0.471 & 0.641 & 0.497 & 0.699 & 0.792 \\
\hline $\mathrm{Na}$ & 0.613 & 0.638 & 0.087 & 0.144 & 0.519 & 0.358 & 0.501 & 0.262 & 0.231 \\
\hline K & 0.032 & 0.027 & 0.001 & 0.001 & 0.015 & 0.015 & 0.02 & 0.039 & 0.009 \\
\hline Catsum & 5.036 & 5.022 & 5.026 & 5.012 & 5.005 & 5.012 & 5.004 & 5.005 & 5.021 \\
\hline \multicolumn{10}{|c|}{ End member } \\
\hline An (wt\%) & 38.04 & 34.87 & 91.55 & 85.74 & 46.87 & 63.21 & 48.82 & 69.90 & 76.74 \\
\hline
\end{tabular}

$\mathrm{B}=$ Barren, $\mathrm{N}=$ Narcondam, gm $=$ groundmass, int=intermediate, n.d.=not determined.

The proportion of opaque oxide is also comparatively high in Narcondam andesite and dacite (up to $40 \%$, table 1). In amphibole andesite, subhedral plagioclase and amphibole occupy almost in equal proportions (table 1 ).

\section{Mineral composition}

\subsection{Plagioclase}

Representative analyses of plagioclase are given in table 2. The composition of plagioclase within the groundmass varies considerably $\left(\mathrm{An}_{35-85}\right)$ in the andesite of Barren islands. Plagioclase phenocrysts are more anorthitic in composition (as high as $\left.A n_{91}\right)$. In contrast, the plagioclase phenocryst from Narcondam island varies in composition from $\mathrm{An}_{44}$ to $\mathrm{An}_{81}$ while the groundmass composition varies from $\mathrm{An}_{47}$ to $\mathrm{An}_{80}$. The plagioclase in amphibole andesite shows restricted compositional variation
$\left(A n_{68-71}\right)$. Plagioclase with 'fritted' band differs from the underlying zone as well as the fresh outer rim (figure 3a). The outer-rim displays relatively high An content $\left(\mathrm{An}_{77}\right)$ as compared to intermediate 'fritted' zone $\left(\mathrm{An}_{70}\right)$ and the inner core $\left(\mathrm{An}_{49}\right)$ (figure $\left.3 \mathrm{a}\right)$. Compositional variation is also noticeable along the width of the plagioclase phenocryst. Figure $4(\mathrm{a}, \mathrm{b})$ is a compilation of EPMA traverses across some of the crystals examined in this study. The plagioclase in andesite varies between labradorite, bytownite and andesine compositions (figure 4a), while in the case of dacite, the compositional trend tends more towards sodic, i.e., the composition varies between andesine and labradorite (figure $4 \mathrm{~b}$ ).

\subsection{Olivine}

Representative analyses of olivine are given in table 3. The forsterite content (Fo) of olivine in Barren island andesite and Narcondam dacite varies 
(a)

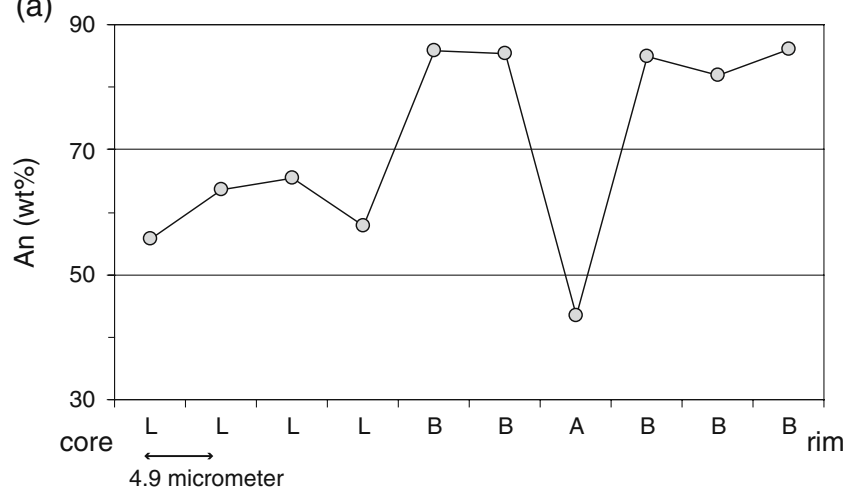

(b)

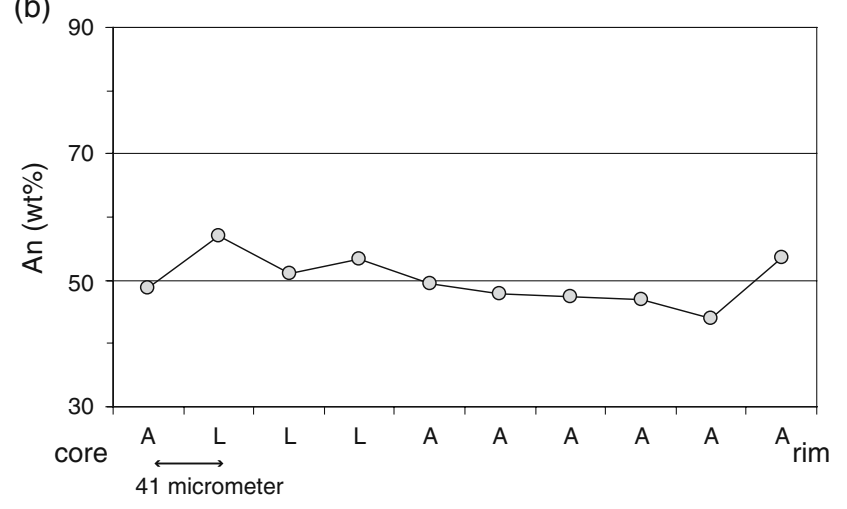

Figure 4. Compositional variation of plagioclase in phenocryst of (a) andesite and (b) dacite. A: andesine, L: labradorite, B: bytownite.

substantially from $\mathrm{Fo}_{70}$ to $\mathrm{Fo}_{88}$. Olivine with reaction corona shows restricted composition $\left(\mathrm{Fo}_{81}\right)$. No major compositional variations are noticed across the olivine grains $\left(\mathrm{Fo}_{82 \text { core }}\right.$ and $\left.\mathrm{Fo}_{83 \text { rim }}\right)$.

\subsection{Orthopyroxene}

Representative analyses of orthopyroxenes and clinopyroxenes are given in table 4. Orthopyroxene occurs as megacryst, phenocryst and microphenocryst as well as a constituent of the groundmass. In general, the orthopyroxene composition varies from $\operatorname{En}_{62}$ to $\operatorname{En}_{72}$, i.e., hypersthene to bronzite. However, where zoned, the inner core is usually Mg-rich $\left(\mathrm{En}_{68}\right)$ while the outer rim is Fe-rich $\left(\mathrm{Fs}_{34}\right)$. Orthopyroxenes encircling the olivine grains (as corona) show compositions similar to enstatite $\left(\mathrm{En}_{65}\right)$ (figure 5a).

\subsection{Clinopyroxene}

Clinopyroxene composition varies from diopsidic to augite. Groundmass composition varies within the range of $\mathrm{Wo}_{31-42}$ and $\mathrm{En}_{45-46}$ (figure 5a).

\subsection{Amphibole}

Amphiboles from amphibole andesite are mostly tschermakite or tschermakitic hornblende (figure 5b).

\subsection{Opaque oxides}

Opaque oxide composition varies from titanomagnetite $\left(\mathrm{FeO} \sim 66-75 \mathrm{wt} \% ; \mathrm{TiO}_{2} \sim 11-21 \mathrm{wt} \%\right)$ to ilmenite ( $\mathrm{FeO} \sim 45-50 \mathrm{wt} \% ; \mathrm{TiO}_{2} \sim 44-48 \mathrm{wt} \%$ ) and mostly occur as microphenocrysts, groundmass or within the plagioclase, pyroxene and olivine as inclusions.

\section{Discussion}

Textural and chemical zoning pattern of crystals have proven to be useful guides in understanding magmatic processes (Dungan and Rhodes 1978). This is due to the fact that during their growth, mineral phases have a tendency to record the processes occurring in the magmatic system, in the form of compositional zones, and, therefore can be used as tracers of the history of the system itself. Thus for instance, the observed variations in the anorthite content even within a single plagioclase crystal (as shown in figure 4) are suggestive of a progressive change in the composition with the crystallization temperature towards a more evolved melt (cf., Batiza and Vanko 1984; Stewart and Fowler 2001).

Magma mixing has been recognized as one of the most important processes involving compositional zoning in mineral phases especially for orogenic magmas related to subduction process (e.g., Pearce 1993; Davidson and Tepley 1997). For example, co-existence of the calcic plagioclase and olivine with limited variation in compositions of the latter (ultimately inhibiting short duration of olivine crystallization), presence of alternate Anrich and An-poor band in plagioclase phenocrysts (for oscillatory-zoned plagioclase) are suggestive of magma mingling in the calc-alkaline rock suite of the Barren and Narcondam islands. 'Fritted' rim as observed in plagioclase phenocryst, erratic An compositional distribution in a few phenocrysts (figure 4), phenocrysts with sodic rim and corroded margins and reaction textures of olivines, indicate the possibility of the andesite and dacite having undergone substantial magma mixing prior to final cooling (cf., Tepley et al 1999; Pal et al 2007). Plagioclase growth and their chemistry (especially An content) further help in understanding the nature of the eruption 
Evidences for magma mixing and petrological implications

Table 3. Representative analyses of olivine.

\begin{tabular}{|c|c|c|c|c|c|c|c|c|c|}
\hline \multirow{2}{*}{$\begin{array}{l}\text { Sample } \\
\text { nos }\end{array}$} & \multicolumn{7}{|c|}{ Barren } & \multicolumn{2}{|c|}{ Narcondam } \\
\hline & B3 & B6 & B6 & B7 & B7 & B7 & B7 & $\mathrm{N} 8$ & N8 \\
\hline Position & Core & Core & Core & Core & Core & Core-corona & Core-corona & Core & Core \\
\hline $\mathrm{SiO}_{2}$ & 37.04 & 37.66 & 37.79 & 37.98 & 37.86 & 38.84 & 38.91 & 40.14 & 38.38 \\
\hline $\mathrm{TiO}_{2}$ & n.d. & 0.04 & n.d. & n.d. & 0.04 & n.d. & n.d. & n.d. & n.d. \\
\hline $\mathrm{Al}_{2} \mathrm{O}_{3}$ & 0.01 & n.d. & 0.02 & 0.03 & 0.04 & 0.01 & 0.03 & 0.05 & 0.02 \\
\hline $\mathrm{Cr}_{2} \mathrm{O}_{3}$ & n.d. & n.d. & n.d. & 0.07 & 0.05 & 0.04 & n.d. & 0.04 & n.d. \\
\hline $\mathrm{FeO}$ & 27.24 & 24.46 & 24.59 & 24.57 & 25.58 & 17.45 & 17.76 & 11.97 & 20.85 \\
\hline $\mathrm{MnO}$ & 0.57 & 0.46 & 0.41 & 0.45 & 0.39 & 0.36 & 0.27 & 0.22 & 0.51 \\
\hline $\mathrm{MgO}$ & 35.37 & 36.35 & 37.29 & 36.53 & 35.65 & 42.06 & 41.76 & 47.16 & 39.47 \\
\hline $\mathrm{CaO}$ & 0.18 & 0.19 & 0.18 & 0.17 & 0.17 & 0.18 & 0.16 & 0.1 & 0.15 \\
\hline $\mathrm{Na}_{2} \mathrm{O}$ & n.d. & 0.01 & 0.03 & n.d. & 0.03 & 0.05 & n.d. & 0.03 & n.d. \\
\hline $\mathrm{K}_{2} \mathrm{O}$ & n.d. & 0.01 & 0.02 & n.d. & n.d. & n.d. & n.d. & 0.03 & n.d. \\
\hline $\mathrm{P}_{2} \mathrm{O}_{5}$ & n.d. & 0 & 0.01 & n.d. & n.d. & n.d. & 0.01 & 0.05 & n.d. \\
\hline Total & 100.41 & 99.18 & 100.34 & 99.81 & 99.81 & 98.99 & 98.9 & 99.79 & 99.38 \\
\hline \multicolumn{10}{|c|}{ Cations based on 4 oxygens } \\
\hline $\mathrm{Si}$ & 0.986 & 1 & 0.992 & 1.002 & 1.003 & 0.999 & 1.002 & 0.997 & 0.999 \\
\hline $\mathrm{Ti}$ & n.d. & 0.001 & n.d. & n.d. & 0.001 & n.d. & n.d. & n.d. & n.d. \\
\hline $\mathrm{Al}$ & n.d. & n.d. & 0.001 & 0.001 & 0.001 & n.d. & 0.001 & 0.001 & 0.001 \\
\hline $\mathrm{Cr}$ & n.d. & n.d. & n.d. & 0.001 & 0.001 & 0.001 & n.d. & 0.001 & n.d. \\
\hline $\mathrm{Fe}$ & 0.606 & 0.543 & 0.54 & 0.542 & 0.567 & 0.375 & 0.382 & 0.249 & 0.454 \\
\hline Mn & 0.013 & 0.01 & 0.009 & 0.01 & 0.009 & 0.008 & 0.006 & 0.005 & 0.011 \\
\hline $\mathrm{Mg}$ & 1.403 & 1.439 & 1.459 & 1.436 & 1.408 & 1.612 & 1.602 & 1.746 & 1.531 \\
\hline $\mathrm{Ca}$ & 0.005 & 0.005 & 0.005 & 0.005 & 0.005 & 0.005 & 0.004 & 0.003 & 0.004 \\
\hline $\mathrm{Na}$ & n.d. & 0.001 & 0.002 & n.d. & 0.002 & 0.002 & n.d. & 0.001 & n.d. \\
\hline K & n.d. & n.d. & 0.001 & n.d. & n.d. & n.d. & n.d. & 0.001 & n.d. \\
\hline Catsum & 3.013 & 2.999 & 3.009 & 2.997 & 2.997 & 3.002 & 2.997 & 3.004 & 3 \\
\hline \multicolumn{10}{|c|}{ End member } \\
\hline Fo & 69.84 & 72.60 & 72.99 & 72.60 & 71.29 & 81.13 & 80.75 & 87.52 & 77.13 \\
\hline
\end{tabular}

n.d.: not determined.

(Stewart and Fowler 2001). For instance, the observed zoning in the plagioclase of Narcondam dacite is likely to have been controlled by significant dissolution and subsequent accretion of high Ca-rich material in the phenocryst. This process also would have been responsible for modulating the An content. Thus, the plagioclase at the final stages grew under non-equilibrium conditions as a result of the mixing event (Stewart and Fowler 2001).

The variety of mineral textures and the compositional variations (especially the plagioclase textures and its varying An content) suggest a hybrid nature of the magma thereby implying distinctly different environments of formation of individual textures and mineral composition, as discussed below.

The widely fluctuating An contents in plagioclase phenocryst may be explained by different melt conditions. The increase in An content suggests that the new melt was compositionally less evolved and possibly hotter and/or wetter. The common occurrences of dissolution and patchy regions in the inner part of the zones support a hotter melt (e.g., Tsuchiyama and Takahasi 1983; Tsuchiyama 1985; Tepley et al 2000). In contrast, the decrease in An content suggests that the melt must have become more evolved and cooler and/or dryer. Thus, fluctuation of An contents suggest variability in the nature of the melt as well as its temperature. Though information on the isotopic composition is necessary to comment on the degree of contamination/magma mixing and also to preclude closedsystem behaviour, based on the observed large compositional changes of plagioclase (An content up to $45 \mathrm{~mol} \%$ ) over short distances ( $5 \mu \mathrm{m}$, figure 4), we interpret that the fluctuating An contents are primarily a function of changes in temperature and composition of melt rather than fluctuation of volatile pressure as proposed by earlier workers (e.g., Tepley et al 2000). The presence of multiple and repeated zoning in plagioclase of andesite and dacite suggest that recharge, assimilation and 
Table 4. Representative analyses of clinopyroxene and orthopyroxene.

\begin{tabular}{|c|c|c|c|c|c|c|c|c|c|}
\hline \multirow{2}{*}{$\begin{array}{l}\text { Sample } \\
\text { nos }\end{array}$} & \multicolumn{7}{|c|}{ Barren } & \multicolumn{2}{|c|}{ Narcondam } \\
\hline & B3 & B3 & B6 & B3 & B7 & B7 & B3 & N8 & N8 \\
\hline Position & Cpx & Gm-Cpx & phenos-cpx & Opx & Opx-corona & Opx-corona & Opx-gm & Cpx-gm & Cpx-gm \\
\hline$\overline{\mathrm{SiO}_{2}}$ & 50.75 & 50.88 & 50.48 & 52.14 & 53 & 52.95 & 53.28 & 48.83 & 49.63 \\
\hline $\mathrm{TiO}_{2}$ & 0.54 & 0.51 & 0.67 & 0.34 & 0.4 & 0.4 & 0.28 & 0.91 & 0.66 \\
\hline $\mathrm{Al}_{2} \mathrm{O}_{3}$ & 2.95 & 2.49 & 3.25 & 1.26 & 0.85 & 0.87 & 0.9 & 5.42 & 5.9 \\
\hline $\mathrm{Cr}_{2} \mathrm{O}_{3}$ & 0.33 & 0.06 & 0.24 & 0.07 & n.d. & n.d. & 0.02 & n.d. & 0.46 \\
\hline $\mathrm{FeO}$ & 7.09 & 7.65 & 7.36 & 18.06 & 17.1 & 17.31 & 17.2 & 7.53 & 4.91 \\
\hline $\mathrm{MnO}$ & 0.13 & 0.22 & 0.12 & 0.54 & 0.48 & 0.6 & 0.68 & 0.25 & 0.16 \\
\hline $\mathrm{MgO}$ & 15.83 & 16.28 & 15.05 & 24.7 & 23.28 & 23.38 & 25.45 & 14.72 & 15.2 \\
\hline $\mathrm{CaO}$ & 22.29 & 21.16 & 22.07 & 2.13 & 3.98 & 4.2 & 1.86 & 22.11 & 22.28 \\
\hline $\mathrm{Na}_{2} \mathrm{O}$ & 0.3 & 0.35 & 0.34 & 0.06 & 0.12 & 0.12 & 0.03 & 0.23 & 0.28 \\
\hline $\mathrm{K}_{2} \mathrm{O}$ & 0.01 & n.d. & n.d. & 0.01 & n.d. & 0.01 & n.d. & n.d. & 0.02 \\
\hline $\mathrm{P}_{2} \mathrm{O}_{5}$ & 0.19 & 0.2 & 0.23 & n.d. & 0.03 & 0.03 & n.d. & 0.25 & 0.14 \\
\hline Total & 100.41 & 99.8 & 99.81 & 99.31 & 99.24 & 99.87 & 99.7 & 100.25 & 99.64 \\
\hline \multicolumn{10}{|c|}{ Cations based on 6 oxygens } \\
\hline $\mathrm{Si}$ & 1.883 & 1.898 & 1.885 & 1.933 & 1.964 & 1.955 & 1.955 & 1.82 & 1.835 \\
\hline $\mathrm{Al}^{\mathrm{IV}}$ & 0.117 & 0.102 & 0.115 & 0.055 & 0.036 & 0.038 & 0.039 & 0.18 & 0.165 \\
\hline $\mathrm{Al}^{\mathrm{VI}}$ & 0.012 & 0.007 & 0.028 & n.d. & 0.001 & n.d. & n.d. & 0.058 & 0.092 \\
\hline $\mathrm{Fe}(\mathrm{iii})$ & 0.13 & 0.133 & 0.099 & 0.093 & 0.031 & 0.058 & 0.055 & 0.13 & 0.065 \\
\hline $\mathrm{Cr}$ & 0.01 & 0.002 & 0.007 & 0.002 & n.d. & n.d. & 0.001 & n.d. & 0.013 \\
\hline $\mathrm{Ti}$ & 0.015 & 0.014 & 0.019 & 0.009 & 0.011 & 0.011 & 0.008 & 0.026 & 0.018 \\
\hline $\mathrm{Fe}(\mathrm{ii})$ & 0.087 & 0.103 & 0.129 & 0.463 & 0.498 & 0.474 & 0.47 & 0.102 & 0.085 \\
\hline $\mathrm{Mn}$ & 0.004 & 0.007 & 0.004 & 0.017 & 0.015 & 0.019 & 0.021 & 0.008 & 0.005 \\
\hline $\mathrm{Mg}$ & 0.875 & 0.905 & 0.838 & 1.365 & 1.286 & 1.287 & 1.392 & 0.818 & 0.838 \\
\hline $\mathrm{Ca}$ & 0.886 & 0.846 & 0.883 & 0.085 & 0.158 & 0.166 & 0.073 & 0.883 & 0.883 \\
\hline $\mathrm{Na}$ & 0.022 & 0.025 & 0.025 & 0.004 & 0.009 & 0.009 & 0.002 & 0.017 & 0.02 \\
\hline K & n.d. & n.d. & n.d. & n.d. & n.d. & n.d. & n.d. & n.d. & 0.001 \\
\hline Catsum & 4.041 & 4.042 & 4.032 & 4.026 & 4.009 & 4.017 & 4.016 & 4.042 & 4.02 \\
\hline \multicolumn{10}{|c|}{ End members } \\
\hline Wo & 44.79 & 42.53 & 45.31 & 4.24 & 8 & 8.36 & 3.67 & 45.68 & 47.19 \\
\hline En & 44.24 & 45.55 & 43.01 & 68.05 & 65.17 & 64.84 & 69.95 & 42.32 & 44.79 \\
\hline Fs & 10.97 & 11.88 & 11.70 & 27.72 & 26.81 & 26.8 & 26.38 & 12 & 8.02 \\
\hline
\end{tabular}

$\mathrm{Cpx}=$ clinopyroxene, $\mathrm{Opx}=$ orthopyroxene, n.d.=not determined.

crystallization might have occurred repeatedly prior to eruption of magma.

Numerous petrographic and experimental studies have suggested that a 'fritted' texture in plagioclase results from the reaction of sodic crystals to a more calcic composition (Kuno 1950; Anderson 1976; Logfren and Norris 1981; Nixon and Pearce 1987; Glazner et al 1988, 1990). The 'fritted' zone consists of micrometer-scale channels of glass and plagioclase irregularly truncating the interior planar growth zones. This texture has been reproduced in the experiments by Tsuchiyama (1985) supporting the hypothesis that large plagioclase crystals are originally from host rhyodacite, some of which were incorporated into a hotter, more calcic magma. If a 'fritted' texture represents the transformation of sodic plagioclase to more calcic compositions by preferential dissolution of the sodic component, composition of the 'fritted' region should be more calcic as compared to the underlying zones. Plagioclase composition (An content) of studied samples display similar characteristics, e.g., 'fritted' zones are relatively more calcic $\left(A n_{55}\right)$ as compared to the underlying zone $\left(\mathrm{An}_{47}\right)$ and less calcic as compared to the overlying rim $\left(\mathrm{An}_{72}\right.$; figure 3, table 2). Alternatively, the 'fritted' texture may also form within plagioclase during episodes of rapid growth and undercooled crystallization (Hibbard 1981; Anderson 1984). However, the textural and compositional relations of Narcondam dacite suggest the 'fritted' texture as having formed the transformation of sodic plagioclase to a more calcic composition rather than rapid growth. 

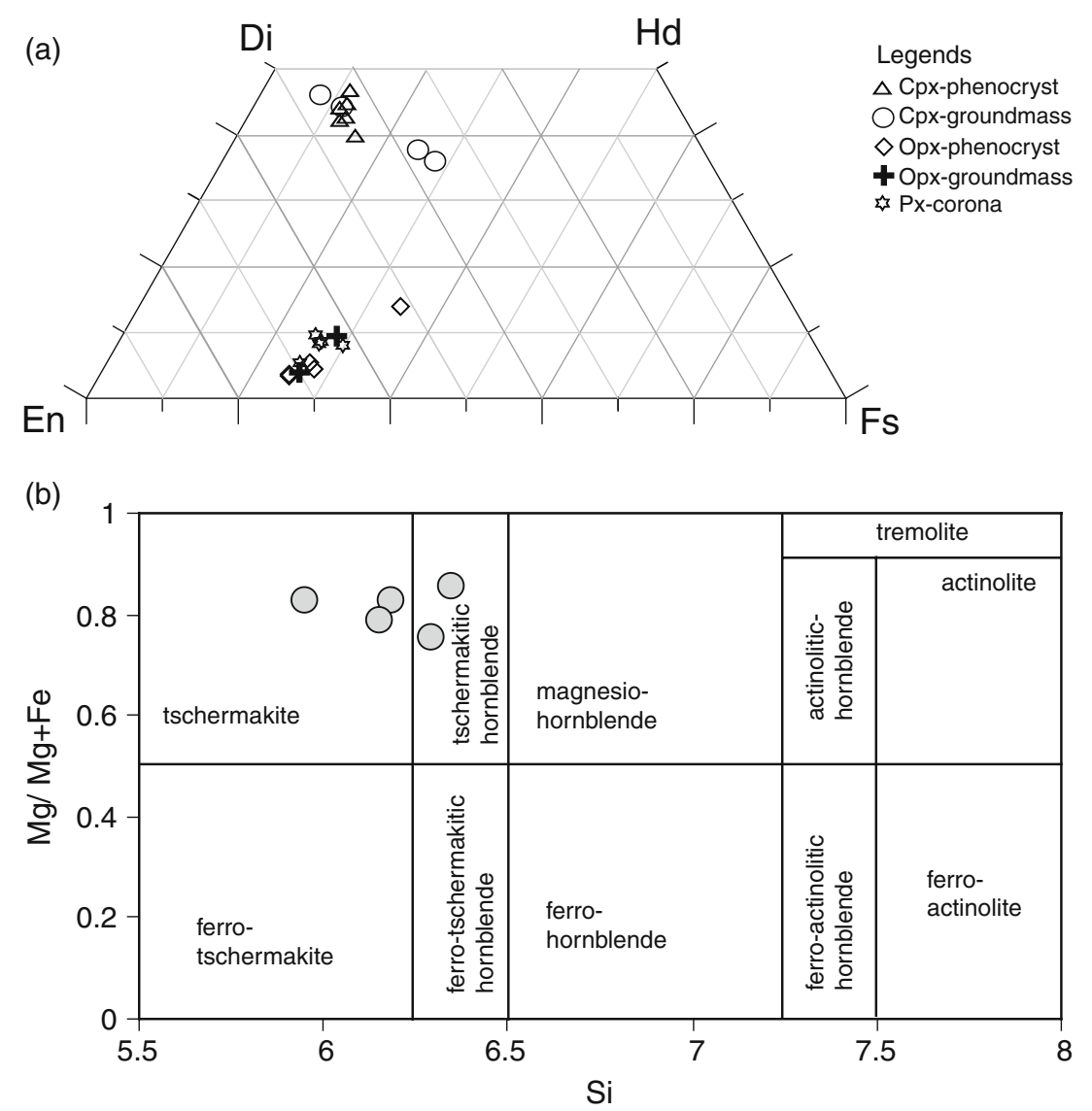

Figure 5. (a) Clinopyroxene and orthopyroxene compositions as plotted in Di-Hd-En-Fs quadrilateral. (b) Amphiboles from amphibole andesite (named after Leake 1978).

Reaction textures have been interpreted as a result of magma mixing (Tepley et al 1999). Disequilibrium results in the formation of mantles or coronas by diffusion-limited reactions along dissolution boundary layers at the margins of crystals (Tsuchiyama 1985). Mg-rich olivine $\left(\sim \mathrm{Fo}_{81}\right)$ in Barren island andesite is rimmed by orthopyroxene $\left(\mathrm{En}_{65}\right)$ of the same composition as the groundmass orthopyroxene $\left(\mathrm{En}_{68}\right.$; figure $3 \mathrm{~b}$, table 3 ). Such a texture is suggestive of rapid growth from a liquid in undercooled conditions. Gradual cooling of the basic magma and its subsequent mingling with acidic magma also enhances the process of replacement of olivine rim by pyroxene grains.

Summing up the above observations, the zoning, the 'fritted' texture and mineral composition of plagioclase as well as the corona texture of olivine crystals clearly bring out the two stages of diverse rock types: andesite and dacite in the area. When a magma intrudes into the host magma chamber, crystals in the vicinity are heated greatly. This process facilitates plagioclase dissolution, formation of patchy or 'fritted' textures, and corona reaction rim around the olivine (phase I, figure 6). The textures and zoning pattern suggest rapid growth from liquid in an undercooled environment which is likely to be maintained at stage I andesitic zone (figure 6). As the injecting and host magmas mix, more anorthitic plagioclase grows on the existing plagioclase phenocryst, resulting in the formation of An-rich rim around the 'fritted' areas (figure 3a). The 'fritted' texture is the result of immersion of sodic plagioclase phenocryst into a hotter melt in equilibrium with the more calcic plagioclase phenocryst. Thoroughly 'fritted' plagioclase in dacite (narrow core with wide 'fritted' rim) may record larger volume of recharge events during later stages in a comparatively cooler environment than the other 'fritted' plagioclase (phase II, figure 6). Variation in composition of the replenishing magmas, initially from a mafic andesite at higher temperature to a silicic dacite at a lower temperature regulates the formation of variegated mineral textures and compositions of Barren and Narcondam volcanic rocks. 


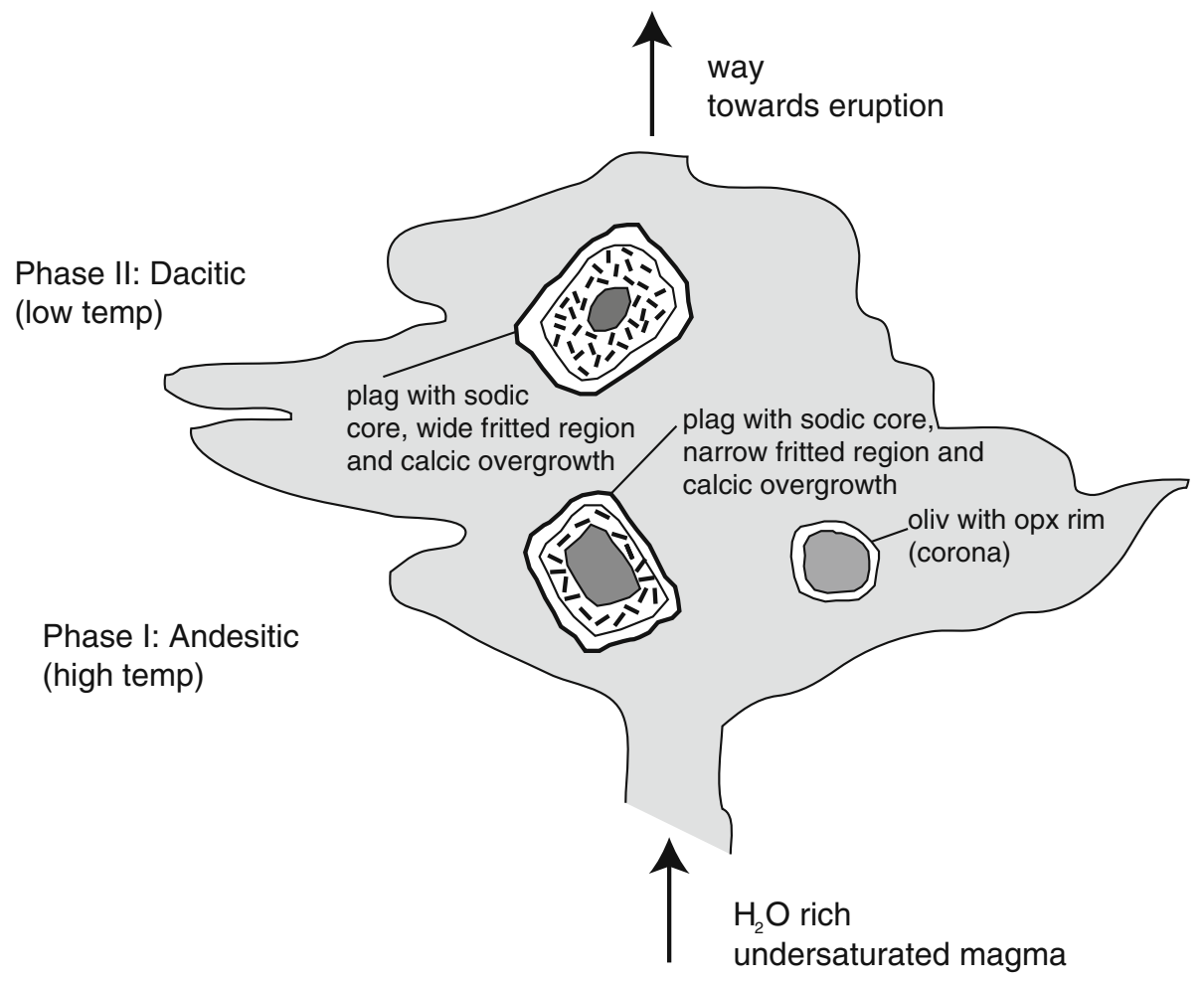

Figure 6. Schematic diagram showing possible spatial relationships between different textures of mineral phases, summarizing their mode of formation. Not to scale.

\section{Conclusions}

Samples from Barren and Narcondam islands comprise both andesite and dacite. Mineralogical study reveals the presence of anomalously calcic and sodic plagioclase, forsteritic olivine, pyroxene (both ortho- and clino-) and minor quartz. Petrographic and microtextural studies suggest mixing of basic (andesitic) and acidic (rhyolitic) magmas as reflected in the different mineral phases. 'Fritting' of plagioclase occurs during the initial stage of hybridization followed by fresh calcic overgrowth. Magma replenishment processes have occurred as two-step processes - intrusion of hotter mafic melt followed by cooler acidic melt.

\section{Acknowledgements}

We sincerely thank Dr Shailesh Nayak, Secretary, Ministry of Earth Sciences (MoES), New Delhi for the keen interest in studies being taken up by NCAOR in the Andaman and Nicobar subduction zone. We are also grateful to the Director, INCOIS, Hyderabad for the financial support. The Indian Coast Guard, New Delhi and A \& N Headquarters, Port Blair and the captain and crew of ICGS Lakshmi Bai are warmly acknowledged for logistics support for carrying out the studies on the Barren and Narcondam islands. We also thank Deputy Director General, Central Petrological Laboratory, Geological Survey of India, Kolkata for the microprobe analyses. We are grateful to Dr Sisir Mondal of the University of Copenhagen, Denmark and the anonymous reviewers for their fruitful comments and suggestions on this manuscript. This is NCAOR contribution 035/2010.

\section{References}

Anderson A T Jr 1976 Magma mixing: Petrologic process and volcanological tool; J. Volcanol. Geotherm. Res. 1 $3-33$.

Anderson A T Jr 1984 Probable relations between plagioclase zoning and magma dynamics, Fuego Yolcano, Guatemala; Am. Min. 69 660-676.

Batiza R and Vanko D 1984 Petrology of young Pacific seamounts; J. Geophys. Res. 89 11,235-11,260.

Chandrasekharam D, Santo A P, Capaccioni B, Vaselli O, Alam M A, Manetti P and Tassi F 2009 Volcanological and petrological evolution of barren island (Andaman Sea, Indian Ocean); J. Asian Earth Sci. 35 469-487.

Coombs M C, Eichelberger J C and Rutherford M J 2002 Experimental and textural constraints on mafic enclave formation in volcanic rocks; J. Volcanol. Geotherm. Res. 119 125-144.

Davidson J P and Tepley F J III 1997 Recharge in volcanic systems: Evidence from isotopic profiles of phenocrysts; Science 275 826-829.

Davidson J P, Tepley F J III, Palacz Z and Meffan Main S 2001 Magma recharge, contamination and residence 
times revealed by in situ laser ablation isotopic analysis of feldspar in volcanic rocks; Earth Planet. Sci. Lett. 184 427-442.

Dungan M A and Rhodes J M 1978 Residual glasses and melt inclusions in basalts from DSDP Legs 45 \& 46: Evidence for magma mixing; Contrib. Mineral. Petrol. 67 142-146.

Eichelberger J C 1978 Andesitic volcanism and crustal evolution; Nature 275 21-27.

Glazner A F, Ussler W III and Mies J W 1988 Fate of granitic minerals in mafic magmas; EOS $\mathbf{7 1} 1504$.

Glazner A F, Ussler W III and Mathis A C 1990 Interpretation of plagioclase texture in volcanic rocks; EOS $\mathbf{7 1}$ 1678.

Hibbard M J 1981 The magma mixing origin of mantled feldspars; Contrib. Mineral. Petrol. 76 158-170.

Izbekov P E, Eichelberger J C, Patino L C, Vogel B V and Ivanov B V 2002 Calcic cores of plagioclase phenocrysts in andesite from Karymsky volcano: Evidence for rapid introduction by basalt replenishment; Geology 30799 802.

Kuno H 1950 Petrology of Hakone volcano and adjacent area, Japan; Bull. Geol. Soc. Am. 61 957-1020.

Leake B E 1978 Nomenclatures of amphiboles; Am. Mineral. 63 1023-1052.

Logfren G E and Norris N 1981 Experimental duplication of plagioclase sieve and overgrowth textures; Geol. Soc. Am. Abstr. Program 13498.

Luhr J F and Halder D 2006 Barren island volcano (NE Indian Ocean): Island-arc high-alumina basalts produced by troctolite contamination; J. Volcanol. Geotherm. Res. 149 177-212.

Nixon G T and Pearce T H 1987 Laser-interferometry study of oscillatory zoning in plagioclase: The record of magma mixing and phenocryst recycling in calc-alkaline chambers, Iztaccihuatl Volcano, Mexico; Am. Mineral. 72 1144-1162.

Pal T, Mitra S K, Sengupta S, Katari A, Bandopadhyay P C and Bhattacharaya A K 2007 Dacite-andesites of
Narcondam volcano in the Andaman sea - an imprint of magma mixing in the inner arc of the AndamanJava subduction system; J. Volcanol. Geotherm. Res. 168 93-113.

Pearce T H 1993 Recent work on oscillatory zoning in plagioclase; In: Feldspars and their reactions (ed.) Parsons I (Dordrecht: Kluwer Academic) pp. 313-349.

Pouchou J-L and Pichoir F 1988 A simplified version of the 'PAP' model for matrix correction in EPMA; In: Microbeam analyses 1988 (ed.) Newbury D E (San Francisco, California: San Francisco Press) pp. 315318.

Radhakrishna M, Lasitha S and Mukhopadhyay M 2008 Seismicity, gravity anomalies and lithospheric structure of the Andaman arc, NE Indian Ocean; Tectonophys. 460 248-262.

Sheth H C, Ray J S, Bhutani R, Kumar A and Smitha R S 2009 Volcanology and eruptive styles of Barren Island: An active mafic stratovolcano in the Andaman sea, NE Indian Ocean; Bull. Volcanol., doi: 10.1007/s00445-0090280-z.

Stewart M L and Fowler A D 2001 The nature and occurrence of discrete zoning in plagioclase from recently erupted andesitic volcanic rocks, Montserrat; J. Volcanol. Geotherm. Res. 106 243-253.

Tepley F J, Davidson J P and Clayne M A 1999 Magmatic interactions as recorded in plagioclase phenocrysts of Chaos crags, Lassen volcanic center, California; J. Petrol. $40787-806$.

Tepley F J, Davidson J, Tilling R I and Arth J G 2000 Magma mixing, recharge and eruptive histories recorded in plagioclase phenocrysts from El Chichon Volcano, Mexico; J. Petrol. 41 1397-1411.

Tsuchiyama A 1985 Dissolution kinetics of plagioclase in the melt of the system diopside-albite-anorthite, and the origin of dusty plagioclase in andesites; Contrib. Mineral. Petrol. 89 1-16.

Tsuchiyama A and Takahasi E 1983 Melting kinetics of a plagioclase feldspar; Contrib. Mineral. Petrol. 84 345-354. 